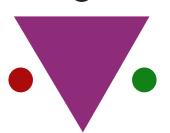

IJCRR

Section: Healthcare

Sci. Journal Impact

Factor: 6.1 (2018)

ICV: 90.90 (2018)

(c) (7) (8)

Copyright@IJCRR

\title{
Awareness on the Role of Health Care Workers in Covid-19 - Need of the Hour
}

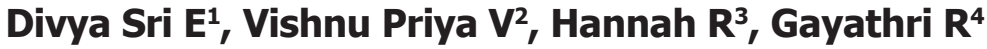

\begin{abstract}
Saveetha Dental College and Hospitals, Saveetha Institute of Medical and Technical Sciences, Saveetha University, Chennai-6ooo77, India; ${ }^{2} \mathrm{De}-$ partment of Biochemistry, Saveetha Dental College and Hospitals, Saveetha Institution of Medical and Technical Sciences, Saveetha University, Chennai- 600077, India; '3epartment of Oral and Maxillofacial Pathology and Microbiology, Saveetha Dental College and Hospitals, Saveetha Institute of Medical and Technical Sciences, Saveetha University, Chennai - 60oo77, India; ${ }^{2}$ Department of Biochemistry, Saveetha Dental College and Hospitals, Saveetha institution of Medical and Technical Sciences, Saveetha University, Chennai-60oo77, India.
\end{abstract}

\section{ABSTRACT}

Introduction: The rapid and extensive spread of the COVID-19 pandemic is a major cause of concern for the healthcare professionals all around the globe. Little is known about the effectiveness of personal protective equipment for healthcare workers who take care of patients infected with the COVID-19.

Materials and Methods: Self-administered questionnaire on the awareness of COVID-19 among healthcare professionals were prepared. The questions were distributed in Google forms and a hundred participants participated. The data were statistically analyzed through SPSS software.

Results and Conclusion: The association between groups was assessed by Chi-square test where $p<0.05$ was considered statistically significant. We have observed that the association between gender and responses to awareness on methods awareness of diagnostic tests for COVID-19 was statistically significant $(p=0.002)$. There is a need for regular educational awareness programs and training programs on infection control practices for COVID-19 across all healthcare professionals. Thus, minimize the risk of transmission to healthcare workers and provide optimal care for patients.

Key Words: COVID-19, Hand sanitizer, Healthcare workers, Hygiene, Face mask, Online survey

\section{INTRODUCTION}

Healthcare workers are particularly vulnerable to this infection ${ }^{1}$. The virus that causes Covid19 was initially called as $2019-\mathrm{nCoV}$ and was then termed as syndrome Coronavirus-2 by the international committee on taxonomy of viruses (ICTV) ${ }^{2}$. It is a strain discovered in 2019 which was not found previously in humans ${ }^{3}$. Previously, the severe acute respiratory syndrome coronavirus (SARS-CoV) and the Middle East respiratory syndrome coronavirus (MERS$\mathrm{CoV}$ ) have been known to affect humans ${ }^{4}$.

Outbreaks of respiratory disease caused by these viruses originated in animals before moving into other hosts like humans ${ }^{5}$. MERS-CoV was found to be transmitted from Arabian camels to humans, whereas SARS-CoV was transmitted from civet cats to humans ${ }^{6}$ SARS -CoV-2 seems to have originated from bats, and the first reports of cases where from Wuhan ${ }^{7}$. Hubei Province in China, suggesting animal to person spread from a live animal market ${ }^{8}$. The virus spread to the entire world and it became a pandemic ${ }^{9}$. Several countries have now reported community spread. The world health organization WHO declared the coronavirus disease as a pandemic on March 11, $2020^{10}$.

With this mode of transmission, healthcare workers are one among the highest risk of being infected ${ }^{11}$. That highly contagious SARS-CoV-2 is an additional hazard for the healthcare system apart from the burden of extended work hours, physical and physiological stress, burn out, and fatigue ${ }^{12}$. The aim of this study is to assess the awareness of the role of health care workers in COVID-19 disease and its related infection control practices among healthcare professionals in the Indian healthcare scenario.

\section{MATERIALS AND METHODS}

The study setting is a prospective observational study. The advantages of this study are economical, easy to create, wide

\section{Corresponding Author:}

Vishnu Priya V, Department of Biochemistry, Saveetha Dental College, Saveetha Institute of Medical \& Technical Sciences, Saveetha University, Chennai-600077, India; Contact: 9841445599; Email: vishnupriya@saveetha.com

ISSN: $2231-2196$ (Print)

Received: 23.07 .2020
ISSN: $0975-5241$ (Online)

Revised: 22.08 .2020
Accepted: 26.09 .2020
Published: 20.10 .2020 
research, gathers larger data, and quick interpretation. This study was approved by the scientific review broad, Saveetha Dental College, Chennai. The method of sampling is simple random sampling. The sample size is a hundred college students. In data collection, the questionnaire is a self-structured questionnaire with 15 questions. The data collection software used is an online Google form link. Methods of representation of each output variable are pie chart and bar diagram. The data is collected and statistically analyzed using SPSS software. Descriptive statistics and association graphs were used to interpret the data.

The following is the Google link for the survey:

https://docs.google.com/forms/d/e/1FAIpQLSflbcAne3q GcYCNP4p25mN4yFVQ6FA2t2Z8QeNPNXQIrGe2zQ/ viewform?usp=sf_link

\section{RESULTS AND DISCUSSION}

$66.34 \%$ are female and $33.66 \%$ are male (figure 1 ). About $17.82 \%$ are using hand sanitizer to protect from the COVID-19 virus, $25.74 \%$ are maintaining social distance, $10.89 \%$ are taking a proper nutritious diet (Figure 2). $44.55 \%$ agreed that coronavirus can enter the human body through nostrils (Figure 3). $69.31 \%$ of participants agreed that healthcare workers are at risk of COVID-19 (Figure 4). 58.42\% of participants are aware of the diagnostic tests for COVID 19 (Figure 5). $73.27 \%$ of participants agreed that COVID-19 pandemic caused stress with its rapid spread (Figure 6). $65.35 \%$ of the participants reported that pandemic will be stress among healthcare workers (Figure 7). COVID-19 might be transmitted from person-to-person showing symptoms like fever, shortness of breath, cough, fatigue which was supported by $48.51 \%$ of the participants (Figure 8 ). $70.30 \%$ of the participants are aware of the symptoms of COVID- 19 (Figure 9). $75.25 \%$ of participants responded that they maintain social distancing after they come back from the hospital (Figure 10).

We have seen the association between gender (X-axis) and responses to awareness on awareness of entry point of coronavirus (Figure 11), responses to awareness on the risk of COVID-19 to health care workers (Figure 12), responses to awareness on the diagnostic test for COVID-19 (Figure 13), responses to awareness on symptoms of COVID-19 (Figure 14).

Since its initial outbreak in China in December 2009, the COVID-19 disease has had a cascading effect worldwide. According to the ICMR update on March 23, 2020, more than 400 individuals have been confirmed positive in India ${ }^{13}$. Isolation of a COVID infected patient is the first step in curbing the spread of COVID-19. In our study, less than half of the responders are aware of COVID-19 ${ }^{14}$. Risk assess- ment and management of healthcare workers with exposure in a healthcare setting to patients with coronavirus disease is evaluated ${ }^{15}$.

Proper hand hygiene practices play a crucial role in preventing the spread of infection. However, the question in our survey was focused on the recommended hand hygiene technique for visibly soiled hands which is handwashing with soap and water for at least 20 seconds with the whole process lasting for up to 40-60 seconds. Awareness of the use of personal protective equipment for suspected/ COVID-19 Cases was high among all groups of healthcare professionals. A facemask /N95 respirator should be used when entering the patient room. The N95 respirator is preferred over facemask when performing or presents for aerosol-generating procedures.

Disposal of used face masks and hand hygiene should be followed throughout. A sterilized dress with disposable face shield and clean non-sterile gloves are recommended upon entry to the patient room area. The patient's isolation and aerosol performing procedures should be carried out in the airborne infection isolation room. Air from these rooms should be filtered and proper ventilation should be available.

Physicians and nurses had significantly better knowledge when compared with other healthcare workers. The current situation requires urgent development of strategies to prevent infection among high-risk populations including preexposure and post-exposure prophylaxis.

Numerous studies in silico analysis ${ }^{16,17}$, natural compounds ${ }^{18}{ }^{124}$, nanomaterials ${ }^{25,26}$, and oncology research ${ }^{27-30}$ improved my passion for research towards epidemiological surveys. The idea for this survey from the current interest in our community

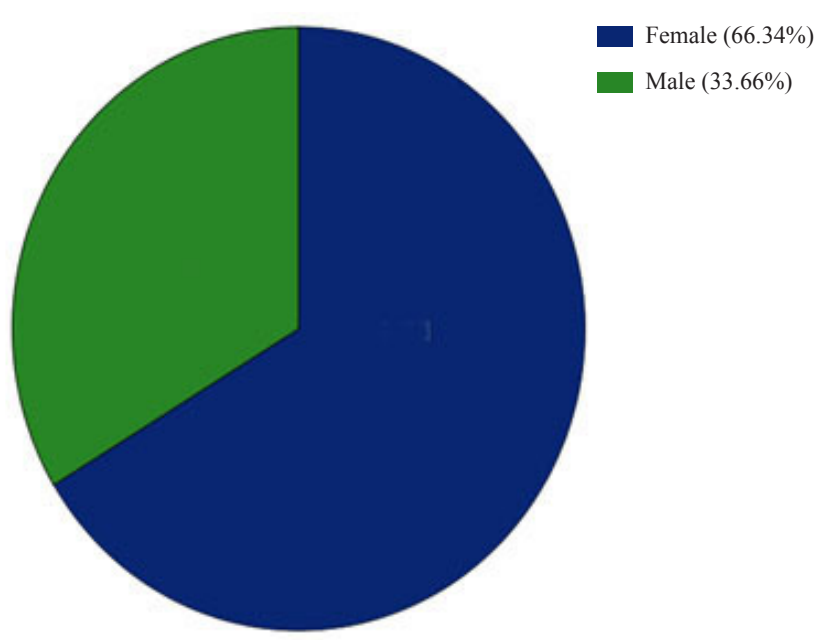

Figure 1: Pie chart showing the percentage distribution of gender among the participants. $33.66 \%$ - Male (green) and $66.34 \%$ - Female (blue). 


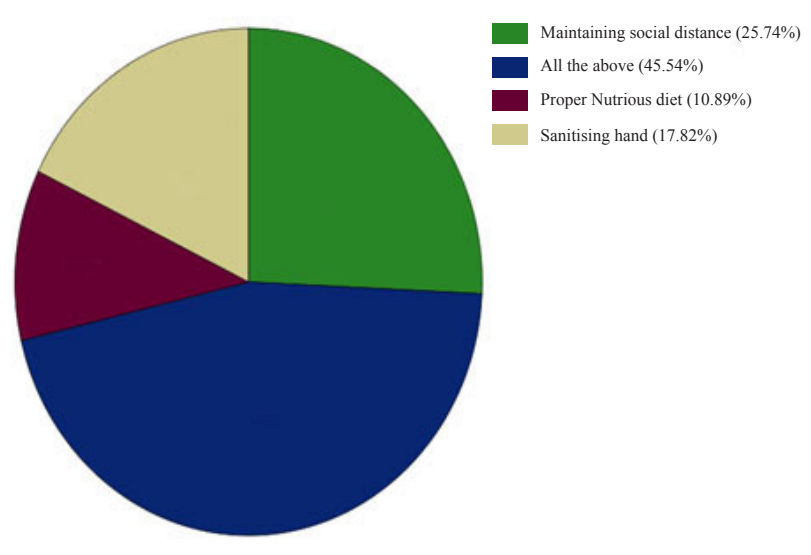

Figure 2: Pie chart showing the percentage distribution of responses about awareness on protective measures for the COVID-19 virus. $25.74 \%$ - Maintaining social distance (green), $10.89 \%$ - proper nutritious diet (purple), 17.82\% - Sanitizing hand (pale yellow), and $45.54 \%$ - all the above (blue).

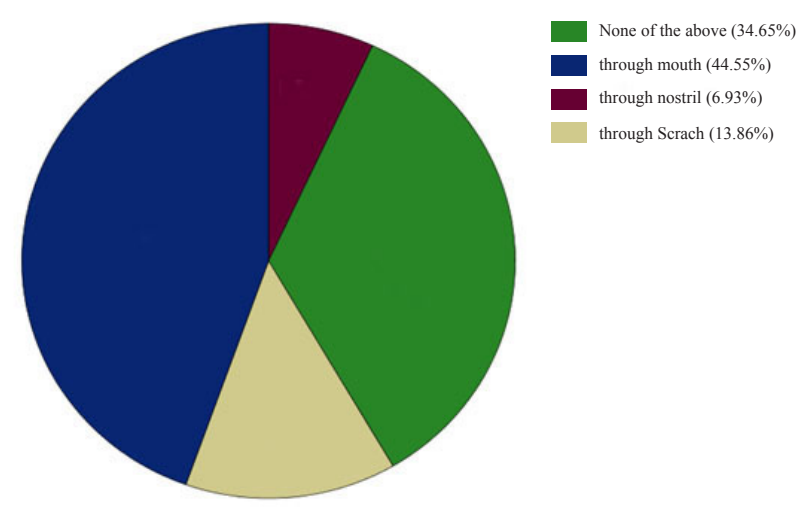

Figure 3: Pie chart showing the percentage distribution of responses about awareness on risk factors for COVID-19. $34.65 \%$ - through mouth (green), $13.86 \%$ - through nostril (pale yellow), $44.55 \%$ - through scratch (blue), and $6.93 \%$ none of the above (purple).

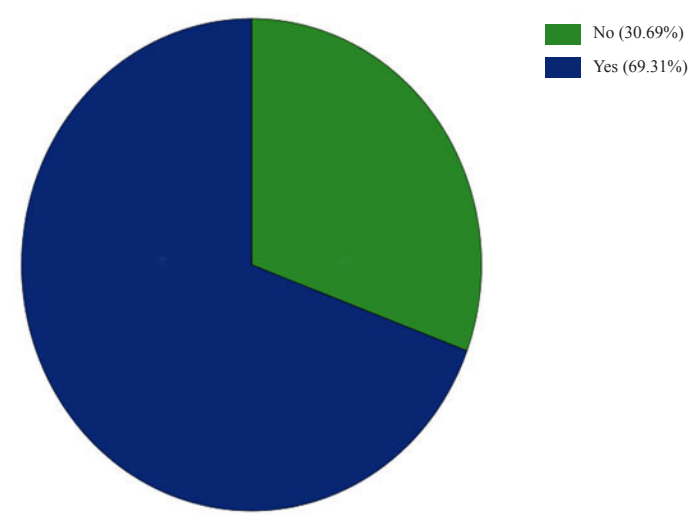

Figure 4: Pie chart showing the percentage distribution of responses about awareness on health care workers at risk from COVID-19. 69.31\% - Yes (blue) and 30.69\% - No (green).

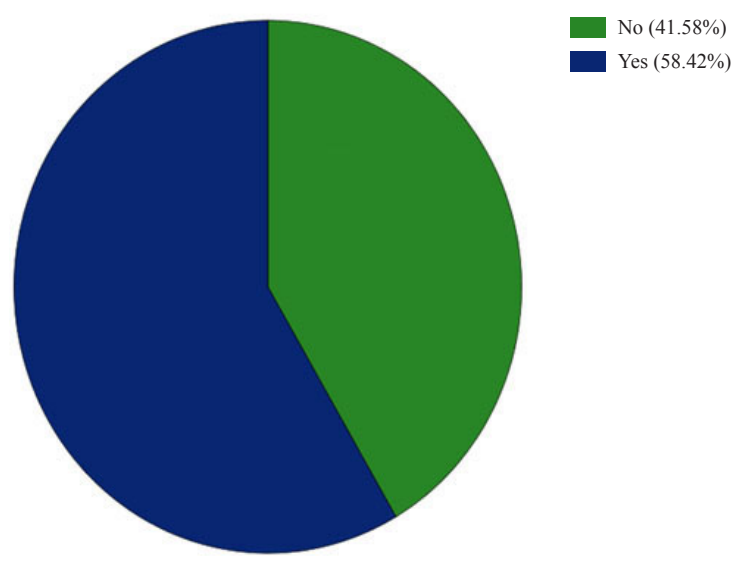

Figure 5: Pie chart showing the percentage distribution of responses about awareness on diagnostic tests for COVID-19. $58.42 \%$ - Yes (blue) and $41.58 \%$ - No (green).

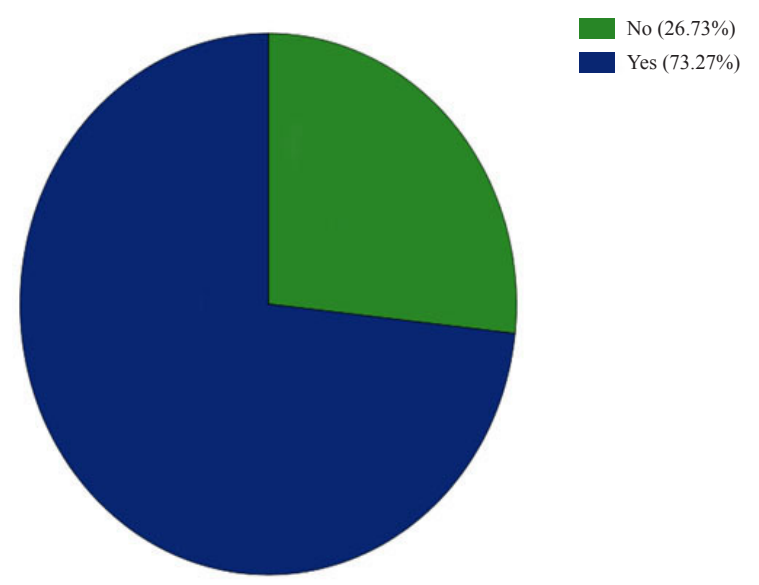

Figure 6: Pie chart showing the percentage distribution of responses about awareness on COVID -19 pandemic and its rapid spread. $73.27 \%$ - Yes (blue) and $26.73 \%$ - No (green).

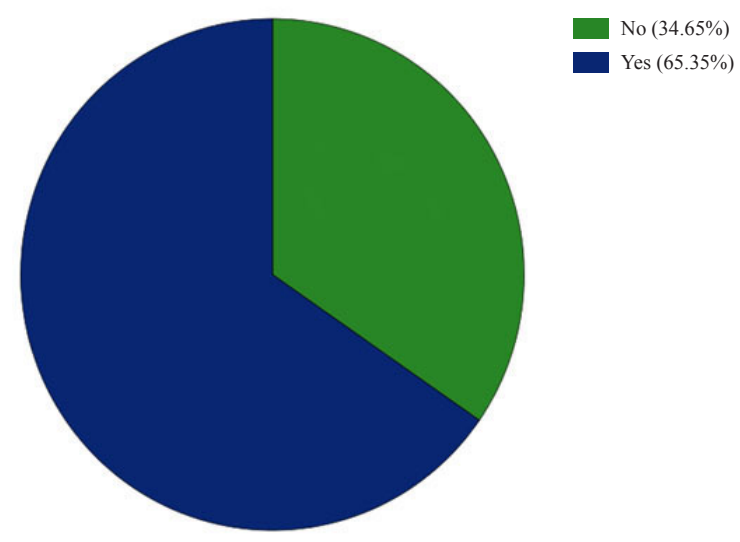

Figure 7: Pie chart showing the percentage distribution of responses about awareness on pandemic to be stress among health care workers. $65.35 \%$ - Yes (blue) and $34.65 \%$ - No (green). 


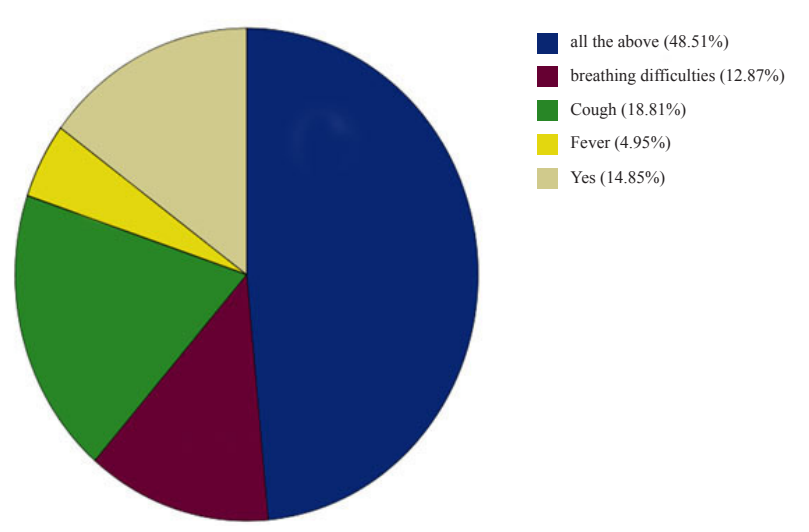

Figure 8: Pie chart showing the percentage distribution of response about awareness on the transmission of COVID-19 from person to person. $4.95 \%$ - fever (yellow), 18.81\% - cough (green), $14.85 \%$ - shortness of breath (pale yellow), $12.87 \%$ - breathing difficulties (purple), and $48.51 \%$ - all the above (blue).

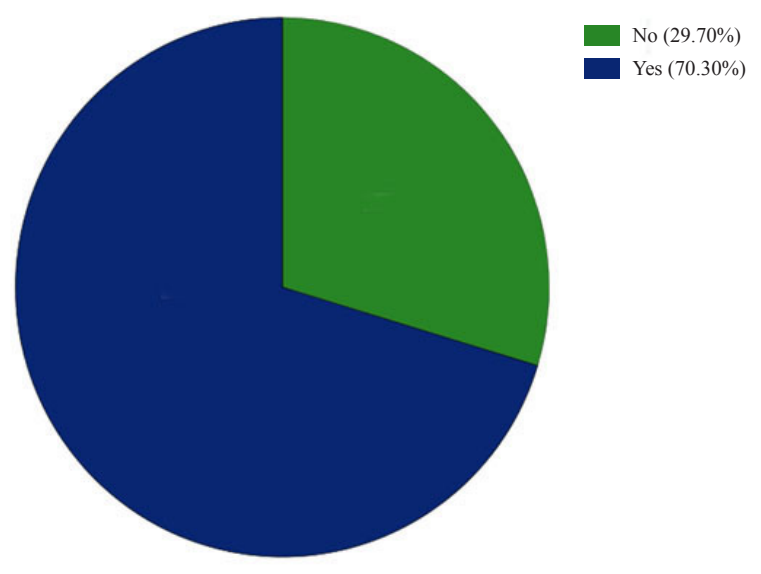

Figure 9: Pie chart showing the percentage distribution of response about awareness on symptoms of COVID - $70.30 \%-$ Yes (blue) and $29.70 \%$ - No (green).

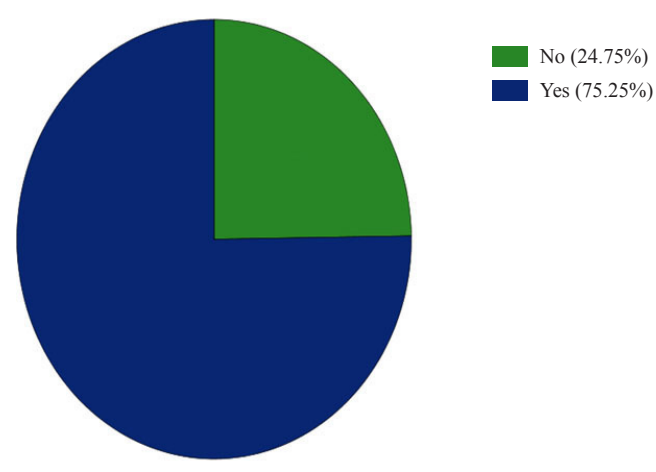

Figure 10: Pie chart showing the percentage distribution of responses about awareness on social distancing from family members after a hospital visit. $75.25 \%$ - Yes (blue) and $24.75 \%$ - No (green).

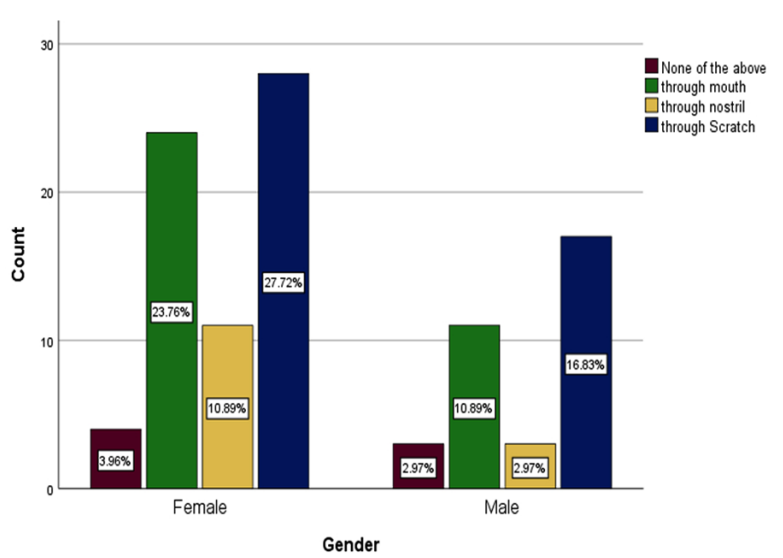

Figure 11: Bar graph represents the association between gender (X-axis) and responses of awareness on routes of entry of the virus into the system (Y-axis). $16.83 \%$ of males and $27.72 \%$ of females reported through open wounds. Blue color denotes through an open wound, green color denotes through the mouth, Yellow color denotes through the nostril, Brown color denotes none of the above. Both males and females were aware of routes of entry of the virus into the system, but in analysis, there was no statistical significance. Majority of the participants in the female population agreed that $(27.72 \%)$ they had good knowledge and awareness on routes of entry of the virus into the system. Chi-square value $=1.623 ; p$-value $=$ 0.654 ( $p>0.05$, statistically not significant).

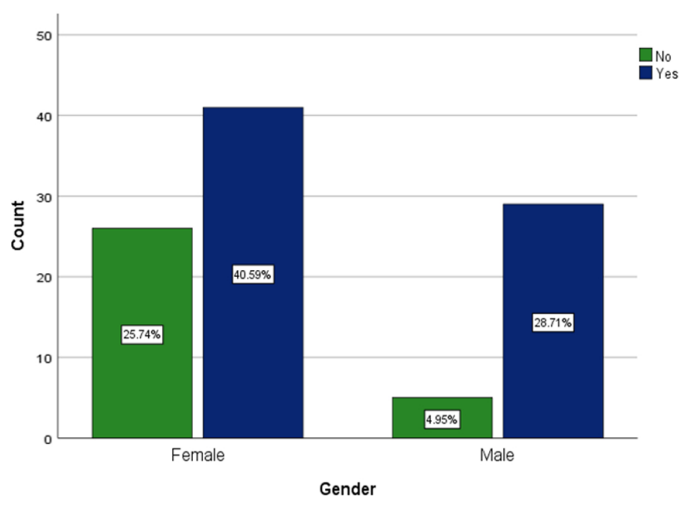

Figure 12: Bar graph represents the association between gender (X-axis) and responses to the awareness on the risk of COVID-19 to health care workers (Y-axis). $28.71 \%$ of males reported Yes and $40.59 \%$ of females reported Yes. Blue color denotes Yes and green color denotes No. Both males and females were aware of the risk factors of COVID-19 to healthcare workers, but in analysis there was no statistical significance. The majority of the participants in the female population agreed that $(40.59 \%)$ they had good awareness on risk of COVID-19 to health care workers. Chi-square value $=6.158$; $p$-value $=0.13$ ( $p>0.05$ statistically not significant). 


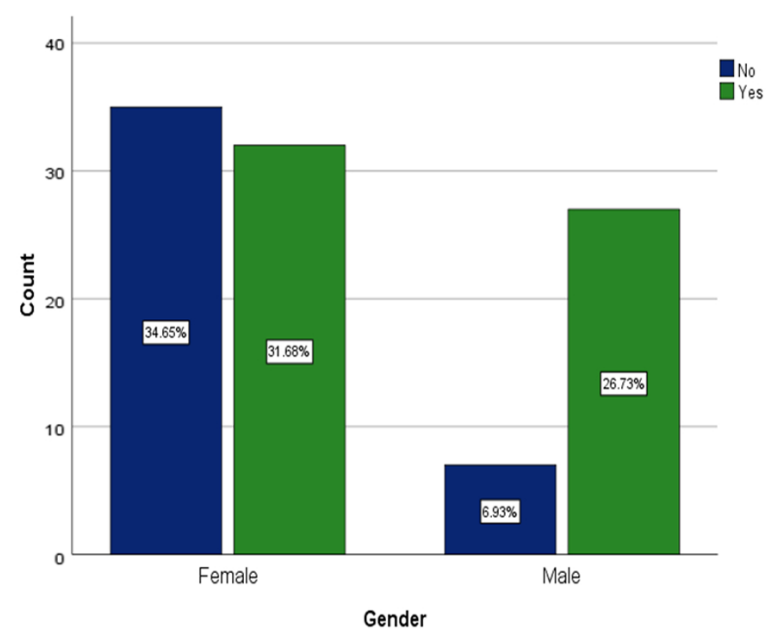

Figure 13: Bar graph represents the association between gender (X-axis) and responses to awareness on diagnostic tests for COVID-19 (Y-axis). 26.73\% of males reported Yes and $31.68 \%$ of females reported Yes. Blue color denotes yes and green color denotes no. Both males and females were aware of diagnostic tests for COVID 19 and this was evident from the results which were statistically significant. Majority of the participants in the female population agreed that (34.65\%) they had good Knowledge and awareness on diagnostic tests for COVID-19. Chi-square value $=9.301 ; \mathrm{P}$-value $=0.002(\mathrm{P}$ $<0.05$, statistically significant).

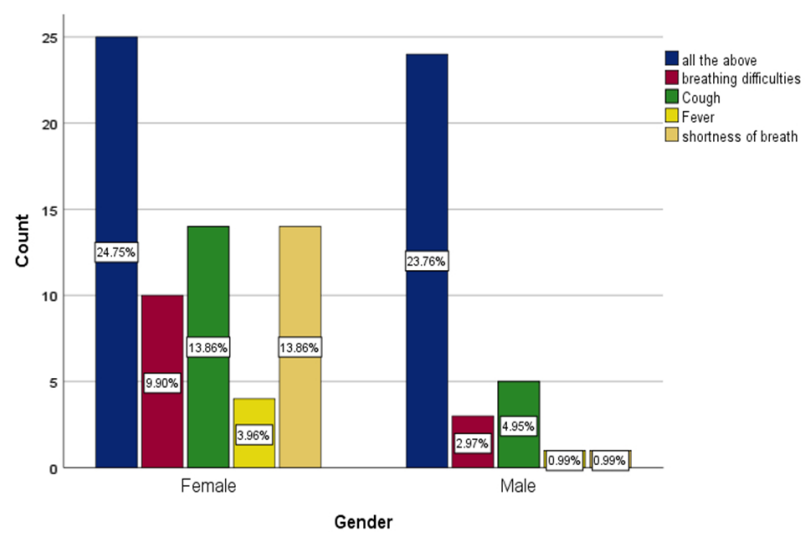

Figure 14: Bar graph represents the association between gender (X-axis) and responses to awareness on symptoms of COVID-19 (Y-axis). $23.76 \%$ of males and $24.75 \%$ of females reported coughing, breathing difficulties, fever, and shortness of breath. Brown color denotes breathing difficulties, green color denotes Cough, yellow color denotes fever, ivory denotes shortness of breath and blue color denotes all the above. Both males and females were aware of symptoms of COVID 19, but in analysis, there was no statistical significance. The majority of the participants in the female population agreed that $(24.75 \%)$ they had good knowledge and awareness of symptoms of COVID-19. Chi-square value $=11.573 ; p$-value $=0.21$ ( $p>0.05$, statistically not significant).

\section{CONCLUSION}

It is important for an individual to have awareness and knowledge about COVID-19, the reasons behind measures like social distancing and the mode of transmission of the virus. It is important to ensure the safety of frontline workers. Moreover, it is important to reduce the risk of infection among healthcare workers. It can be done by implementing policies and educating the people to convey the importance and the consequences of the virus transmission, we can conclude that adequate awareness can be created on the role of healthcare workers in COVID-19. This study shows the strong need to implement periodic educational programs and training programmes for COVID-19.

\section{ACKNOWLEDGEMENT}

We thank Saveetha Dental College for providing us the support to conduct the study.

\section{Conflict of Interest}

All the authors declare no conflict of interest in the study.

\section{Funding Information}

None

\section{REFERENCES}

1. Langade D, Modi PD, Sidhwa YF, Hishikar NA, Gharpure AS, Wankhede K, et al. Burnout Syndrome Among Medical Practitioners Across India: A Questionnaire-Based Survey [Internet]. Cureus. 2016. Available from: http://dx.doi.org/10.7759/ cureus. 771

2. Cascella M, Cuomo A, Viscardi D. Features and Management of the Pelvic Cancer Pain [Internet]. 2016. Available from: http:// dx.doi.org/10.1007/978-3-319-33587-2

3. Modi PD, Kumar P, Solanki R, Modi J, Chandramani S, Gill N. Hand Hygiene Practices Among Indian Medical Undergraduates: A Questionnaire-Based Survey [Internet]. Cureus. 2017. Available from: http://dx.doi.org/10.7759/cureus.1463

4. Feng S, Shen C, Xia N, Song W, Fan M, Cowling BJ. Rational use of face masks in the COVID-19 pandemic [Internet]. Vol. 8, The Lancet Respiratory Medicine. 2020. p. 434-6. Available from: http://dx.doi.org/10.1016/s2213-2600(20)30134-x

5. Abbag HF, El-Mekki AA, Al Bshabshe AAA, Mahfouz AA, AlDosry AA, Mirdad RT, et al. Knowledge and attitude towards the Middle East respiratory syndrome coronavirus among healthcare personnel in the southern region of Saudi Arabia [Internet]. Vol. 11, Journal of Infection and Public Health. 2018. p. 720-2. Available from: http://dx.doi.org/10.1016/j.jiph.2018.02.001

6. Alsahafi A, Cheng A. Knowledge, Attitudes and Behaviours of Healthcare Workers in the Kingdom of Saudi Arabia to MERS Coronavirus and Other Emerging Infectious Diseases [Internet]. Vol. 13, International Journal of Environmental Research and Public Health. 2016. p. 1214. Available from: http://dx.doi. org/10.3390/ijerph13121214

7. Mitjà $\mathrm{O}$, Clotet $\mathrm{B}$. Use of antiviral drugs to reduce COVID-19 transmission [Internet]. Vol. 8, The Lancet Global Health. 2020. 
p. e639-40. Available from: http://dx.doi.org/10.1016/s2214$109 x(20) 30114-5$

8. Ilesanmi O, Alele FO. Knowledge, Attitude and Perception of Ebola Virus Disease among Secondary School Students in Ondo State, Nigeria, October, 2014 [Internet]. PLoS Currents. 2016. Available from: http://dx.doi.org/10.1371/currents.outbreaks. c04b88cd5cd03cccb99e125657eecd76

9. Johnson EJ, Hariharan S. Public health awareness: knowledge, attitude and behaviour of the general public on health risks during the H1N1 influenza pandemic [Internet]. Vol. 25, Journal of Public Health. 2017. p. 333-7. Available from: http://dx.doi. org/10.1007/s10389-017-0790-7

10. McCloskey B, Zumla A, Ippolito G, Blumberg L, Arbon P, Cicero A, et al. Mass gathering events and reducing further global spread of COVID-19: a political and public health dilemma [Internet]. Vol. 395, The Lancet. 2020. p. 1096-9. Available from: http://dx.doi.org/10.1016/s0140-6736(20)30681-4

11. Khatri DAK, MGM Medical College Indore, India MP. Health Problems among Sanitation Workers in Indore City and Their Knowledge, Attitude \& Practices Regarding Preventive Measures Taken At Workplace: A Cross- Sectional Study [Internet]. Vol. 6, Journal of Medical Science And clinical Research. 2018. Available from: http://dx.doi.org/10.18535/jmscr/v6i5.28

12. Rubin GJ, Amlot R, Page L, Wessely S. Public perceptions, anxiety, and behaviour change in relation to the swine flu outbreak: cross sectional telephone survey [Internet]. Vol. 339, BMJ. 2009. p. b2651-b2651. Available from: http://dx.doi.org/10.1136/bmj. b2651

13. Yao H, Chen J-H, Xu Y-F. Rethinking online mental health services in China during the COVID-19 epidemic [Internet]. Vol. 50, Asian Journal of Psychiatry. 2020. p. 102015. Available from: http://dx.doi.org/10.1016/j.ajp.2020.102015

14. Abebe TB, Bhagavathula AS, Tefera YG, Ahmad A, Khan MU, Belachew SA, et al. Healthcare professionals' awareness, knowledge, attitudes, perceptions and beliefs about Ebola at Gondar University Hospital, Northwest Ethiopia: a cross-sectional study [Internet]. Vol. 7, Journal of Public Health in Africa. 2016. Available from: http://dx.doi.org/10.4081/jphia.2016.570

15. Banerjee D. The COVID-19 outbreak: Crucial role the psychiatrists can play [Internet]. Vol. 50, Asian Journal of Psychiatry. 2020. p. 102014. Available from: http://dx.doi.org/10.1016/j. ajp. 2020.102014

16. Ponnulakshmi R, Shyamala Devi B, Vijayalakshmi P, Selvaraj J. In silico and in vivo analysis to identify the antidiabetic activity of beta sitosterol in adipose tissue of high fat diet and sucrose induced type-2 diabetic experimental rats. Toxicol Mech Methods. 2019 May;29(4):276-90.

17. Wu F, Zhu J, Li G, Wang J, Veeraraghavan VP, Mohan SK, et al. Biologically synthesized green gold nanoparticles from Siberian ginseng induce growth-inhibitory effect on melanoma cells (B16) [Internet]. Vol. 47, Artificial Cells, Nanomedicine, and Biotechnology. 2019. p. 3297-305. Available from: http:// dx.doi.org/10.1080/21691401.2019.1647224

18. Ke Y, Al Aboody MS, Al Turaiki W, Alsagaby SA, Alfaiz FA, Veeraraghavan VP, et al. Photosynthesized gold nanoparticles from Catharanthus roseus induces caspase-mediated apoptosis in cervical cancer cells (HeLa) [Internet]. Vol. 47, Artificial Cells, Nanomedicine, and Biotechnology. 2019. p. 1938-46. Available from: http://dx.doi.org/10.1080/21691401.2019.1614017

19. Ma Y, Karunakaran T, Veeraraghavan VP, Mohan SK, Li S. Sesame Inhibits Cell Proliferation and Induces Apoptosis through Inhibition of STAT-3 Translocation in Thyroid Cancer Cell Lines (FTC-133) [Internet]. Vol. 24, Biotechnology and Bioprocess Engineering. 2019. p. 646-52. Available from: http:// dx.doi.org/10.1007/s12257-019-0151-1

20. Li Z, Veeraraghavan VP, Mohan SK, Bolla SR, Lakshmanan H, Kumaran S, et al. Apoptotic induction and anti-metastatic activity of eugenol encapsulated chitosan nanopolymer on rat glioma C6 cells via alleviating the MMP signaling pathway [Internet]. Vol. 203, Journal of Photochemistry and Photobiology B: Biology. 2020. p. 111773. Available from: http://dx.doi.org/10.1016/j. jphotobiol.2019.111773

21. Chen F, Tang Y, Sun Y, Veeraraghavan VP, Mohan SK, Cui C. 6-shogaol, a active constituents of ginger prevents UV radiation mediated inflammation and oxidative stress through modulating $\mathrm{NrF} 2$ signaling in human epidermal keratinocytes (HaCaT cells) [Internet]. Vol. 197, Journal of Photochemistry and Photobiology B: Biology. 2019. p. 111518. Available from: http://dx.doi. org/10.1016/j.jphotobiol.2019.111518

22. Wang Y, Zhang Y, Guo Y, Lu J, Veeraraghavan VP, Mohan SK, et al. Synthesis of Zinc oxide nanoparticles from Marsdenia tenacissima inhibits the cell proliferation and induces apoptosis in laryngeal cancer cells (Hep-2) [Internet]. Vol. 201, Journal of Photochemistry and Photobiology B: Biology. 2019. p. 111624. Available from: http://dx.doi.org/10.1016/j.jphotobiol.2019.111624

23. Gan H, Zhang Y, Zhou Q, Zheng L, Xie X, Veeraraghavan VP, et al. Zingerone induced caspase-dependent apoptosis in MCF7 cells and prevents 7,12-dimethylbenz(a)anthracene-induced mammary carcinogenesis in experimental rats [Internet]. Vol. 33, Journal of Biochemical and Molecular Toxicology. 2019. Available from: http://dx.doi.org/10.1002/jbt.22387

24. Mohan SK, Veeraraghavan VP, Jainu M. Effect of pioglitazone, quercetin, and hydroxy citric acid on vascular endothelial growth factor messenger RNA (VEGF mRNA) expression in experimentally induced nonalcoholic steatohepatitis (NASH) [Internet]. Vol. 45, Turkish journal of medical sciences.2015. p. 542-6. Available from: http://dx.doi.org/10.3906/sag-1404-136

25. Rengasamy G, Venkataraman A, Veeraraghavan VP, Jainu M. Cytotoxic and apoptotic potential of Myristica fragrans Houtt. (mace) extract on human oral epidermal carcinoma KB cell lines [Internet]. Vol. 54, Brazilian Journal of Pharmaceutical Sciences. 2018. Available from: http://dx.doi.org/10.1590/s217597902018000318028

26. G R, Ramya G, V VP, Gayathri R. Cytotoxicity of strawberry extract on oral cancer cell line [Internet]. Vol. 11, Asian Journal of Pharmaceutical and Clinical Research. 2018. p. 353. Available from: http://dx.doi.org/10.22159/ajpcr.2018.v11i9.25955

27. Mala M, Srividya S. Partial purification and properties of a laundry detergent compatible alkaline protease from a newly isolated Bacillus species Y [Internet]. Vol. 50, Indian Journal of Microbiology. 2010. p. 309-17. Available from: http://dx.doi. org/10.1007/s12088-010-0024-y

28. Menon A, V VP, Gayathri R. Preliminary phytochemical analysis and cytotoxicity potential of pineapple extract on oral cancer cell lines [Internet]. Asian Journal of Pharmaceutical and Clinical Research. 2016. p. 140. Available from: http://dx.doi. org/10.22159/ajpcr.2016.v9s2.13313

29. Jainu M, Priya V, Mohan S. Biochemical evidence for the antitumor potential of Garcinia mangostana Linn. On diethylnitrosamine-induced hepatic carcinoma [Internet]. Vol. 14, Pharmacognosy Magazine. 2018. p. 186. Available from: http://dx.doi. org/10.4103/pm.pm_213_17

30. Shruti, Vishnupriya, V,. Gayathri, Sharma G, Patnaik S. Awareness in childhood obesity. 2016. Research Journal of Pharmacy and Technology 9(10),pp 1658-1662.Available from: http:// dx.doi.org/10.1063/1.4918178 